\title{
POLA KOMUNIKASI PADA ACARA RITUAL RUWATAN POTONG RAMBUT GEMBEL DI DIENG WONOSOBO
}

\author{
Wiyanto Hidayatullah \\ Fakultas Ilmu Komunikasi, Universitas Mercu Buana Jakarta \\ wiyanto.hidayatullah@mercubuana.ac.id
}

\begin{abstract}
Dreadlocks Ruwatan is a hair cutting ceremony for children with dreadlocks (gembel) performed by people in the Dieng Plateau (Dieng Plateau), Central Java. Ruwatan ritual which is held on the first Suro according to the Javanese Calendar aims to clean or free dreadlocks children from sukerta / sesuker (bad luck, sadness, or disaster). The belief that children with dreadlocks are descendants of Kiai Kolodete or entrusted Kanjeng Ratu Kidul (Nyai Roro Kidul) has become amyth hereditaryin the lives of the Dieng people. They also believe that dreads should only be cut if the child in question has the will / asked for it and must be done throughrituals ruwat or ruwatanled by local traditional elders. This sentence can only be done after the parents fulfill the "whatever" request submitted by the child. It is said that if the cutting of dreads is not done through a sacred ritual, dreads will grow back and the child tends to be sick. This research uses literature review, intercultural communication, culture, verbal messages, nonverbal messages communication patterns, socialization, ritual rituals. This research is a cultural heritage of the Dieng Plateau which is passed down through culture through socialization media, without them being affected by the effects of globalization. Saram conveyed that the Dieng plateau community should not only maintain a trasidi but also have a moral and social message so that they can be accounted for in the local area of residence.
\end{abstract}

Keyword: ruwatan, symbolism, cultural communication patterns

\begin{abstract}
Abstrak. Ruwatan rambut gimbal adalah upacara pemotongan (cukur) rambut pada anak-anak berambut gimbal (gembel) yang dilakukan oleh masyarakat di daerah Dataran Tinggi Dieng (Dieng Plateau), Jawa Tengah. Ritual ruwatan yang diadakan pada tanggal satu Suro menurut Kalender Jawa ini bertujuan untuk membersihkan atau membebaskan anak-anak berambut gimbal dari sukerta/sesuker (kesialan, kesedihan, atau malapetaka). Kepercayaan bahwa anak-anak berambut gimbal adalah keturunan Kiai Kolodete atau titipan Kanjeng Ratu Kidul (Nyai Roro Kidul) menjadi mitos turun-temurun dalam kehidupan masyarakat Dieng. Mereka juga percaya bahwa rambut gimbal hanya boleh dipotong bila anak yang bersangkutan sudah menghendaki/memintanya dan harus dilakukan melalui ritual ruwat atau ruwatan yang dipimpin tetua adat setempat. Ruwatan ini hanya dapat dilakukan setelah orang tua memenuhi permintaan "apa pun" yang diajukan oleh sang anak. Konon jika pemotongan rambut gimbal tidak dilakukan melalui ritual sakral, rambut gimbal akan kembali tumbuh dan si anak cenderung sakit-sakitan. Penelitian ini menggunakan tinjauan pustaka, komunikasi antarbudaya, kebudayaan, pesan verbal, pesan nonverbal, pola komunikasi, sosialisasi, ritual ruwatan. penelitian ini adalah sebuah warisan budaya dari dataran tinggi Dieng yang turunmenurun diturunkan kebudayaannya melalui media-media sosialisasi, tanpa mereka terpengaruh dari efek globalisasi yang ada. Saram yang disampaikan hendaknya masyarakat dataran tinggi Dieng tidak hanya sekedar mempertahankan suatu trasidi tetapi memiliki pesan moral dan sosial agar dapat dipertanggungjawabkan keberadaannya di lingkungan tempat tinggal daerah setempat.
\end{abstract}

Kata Kunci: ruwatan, simbolisme, pola komunikasi budaya

\section{Pendahuluan}

Indonesia terdiri atas beribu-ribu pulau yang penuh dengan aneka ragam suku bangsa dan kebudayaan. Setiap suku bangsa di Indonesia menciptakan, menyebarluaskan dan mewariskan kebudayaan masing-masing dari satu generasi ke generasi berikutnya. Keanekaragaman kebudayaan pada setiap suku bangsa di Indonesia menunjukkan kekayaan kebudayaan Nusantara. Masing- 
masing daerah di Indonesia memiliki corak kebudayaan yang berbeda-beda. Kebudayaan daerah adalah akar dari kebudayaan nasional. Oleh karena itu kebudayaan daerah harus dilestarikan dan dipertahankan (Koentjaraningrat, 1980).

Salah satu usaha dalam mempertahan kebudayaan ini adalah cara sosialisasi dari masyarakat agar suatu kebudayaan tersebut tetap dapat diturunkan secara turun menurun dimana diperlukan komunikasi dalam menyosialisasikannya. Sosialisasi ini sendiri adalah perbedaan penting antara manusia dengan makhluk lain. Berbeda dengan mahkluk lain yang seluruh perilakunya dikendalikan oleh naruli yang diperoleh sejak awal hidupnya. Oleh sebab itu manusia kemudian mengembangkan kebudayaan untuk mengisi kekosongan yang tidak diisi oleh naluri. Kebiasaan-kebiasaan yang berkembang dalam tiap kelompok tersebut kemudian menghasilkan bermacam-macan sistem yang berbeda satu dengan yang lain.

Keseluruhan kebiasaan yang dipunyai manusia tersebut dibidang ekomoni, kekeluargaan, pendidikan, agama, politik dan sebagainya. Harus dipelajari oleh setiap anggota baru suatu masyarakat melalui suatu proses yang dinamakan sosialisasi (socialization) (Sunarto, 2004). Dari proses sosialisasi ini dimana setiap agen-agen sosialisasi ini menggunakan komunikasi untuk menyampaikan pesan dan bersosialisasi dalam bermasyarakat. Dalam konteks kebudayaan komunikasi diperlukan untuk menyosialisasikan suatu kebudayaan kedalam masyarakat itu sendiri dan masyarakat luar, dimana pola komunikasi mereka dalam menyosialisasikan suatu kebudayan ini ditentukan. Pola komunikasi ini sendiri yaitu suatu bentuk arus penyampaian pesan yang biasanya telah menjadi sistem dalam sebuah kelompok atau organisasi yang dapat berkembang sesuai dengan kebutuhan dan perkembangan kelompok atau organisasi tersebut (Morissan, 2009).

Salah satu kebudayan yang masih bertahan dan terus dipertahankan adalah "Ruwatan Potong Rambut Gimbel Di Dieng Wonosobo" ritual yang setiap tahunnya diadakan mengandung aspek simbol-simbol baik simbol verbal maupun symbol non verbal pada setiap tata cara ritual tersebut. Ruwatan tersebut merupakan ritual sakral dengan tujuan untuk membebaskan,membersihkan seseorang sesuatu yang dipandang tidak baik atau buruk serta jahat. Ruwatan sebagai salah satu warisan upacara tradisional jawa sampai sekarang masih dilestarikan. Terlestarinya upacara ini oleh karena keberadaan nya memang dianggap masih bermanfaat (Thoyib, 1989). Komponen dan makna komponen dalam Ritual Ruwatan Potong Rambut Gembel adalah untuk memohon keselamatan pada Tuhan Yang Maha Esa agar melimpahkan rejeki dan keselamatan kepada masyarakat Desa DiengWonosobo Jawa Tengah pada khususnya dan seluruh masyarakat Indonesia pada umumnya.

Pada saat ini orang sudah melupakan budaya dan tradisi dari Negara sendiri karena pengaruh dari globalisasi yang ada, sehingga membuat kesenian dari kebudayaan dan tradisi yang ada di Indonesia mulai terkikis. Tanpa tahu makna dan cara menyosialisasikan kebudayaan ini agar tetap bertahan hingga sekarang walaupun diterpa oleh efek gobalisasi. Tujuan masyarakat Dieng menyosialisasikan ritual ruwatan gembel ini selain demi mempertahankan warisan budaya tapi juga masyarakat Dieng ini inginmembentuk identitas sosial. Dalam komunikasi antarbudaya identitas ini adalah fungsi dari komunikasi antarbudaya dimana identitas sosial yaitu terbentuk melalui narasi tentang diri dalam proses sosial dengan menggunakan materi-materi yang dimiliki bersama secara sosial. Biasanya proses tersebut dikenal sebagai sosialisasi atau akulturasi. Tanpa sosialisasi kita tidak akan menjadi orang sebagaimana yang kita pahami dalam kehidupan sehari-hari.

Dalam membentuk identitas sosial dan cara mempertahankan warisan budaya dari Dataran Tinggi Dieng, maka masyakarat, pemerintah daerah dan pemangku adat setempat berkerja sama dalam menyososialisasikan ritual ruwatan potong rambut gembel ini, dimana dalam menyosialisasikan terdapat pola-pola komunikasi dalam menyampaikan sosialisasi ini. Dalam 
melakukan komunikasi, diperlukan suatu proses yang memungkinkannya untuk melakukan komunikasi secara efektif. Proses komunikasi inilah membuat komunikasi berjalan dengan baik untuk mencapai tujuannya. Adanya proses komunikasi, berarti terdapat suatu alat yang digunakan

sebagai cara dalam berkomunikasi. Pengertian dari pola komunikasi adalah proses yang dirancang untuk mewakili kenyataan keterpautannya unsur-unsur yang di cakup beserta keberlangsunganya. Hal ini untuk memudahkan pemikiran secara sistematik dan logis. Komunikasi adalah salah satu bagian dari hubungan antar manusia baik individu maupun kelompok dalam kehidupan sehari-hari dari pengertian ini jelas bahwa komunikasi melibatkan sejumlah orang dimana seorang menyatakan sesuatu kepada orang lain, jadi yang terlibat dalam komunikasi itu adalah manusia itu juga (Mulyana, 2007)

\section{METODE PENELITIAN}

Penelitian ini menggunakan paradigma positivis, untuk menemukan atau memperoleh konfirmasi tentang hubungan sebab akibat yang biasa dipergunakan untuk memprediksi pola-pola umum suatu gejala sosial atau aktivitas manusia (Newman, 2003). Variabel-variabel pada penelitian ini dianalisa melalui hypotethico-deductive. method, yaitu suatu metode yang melibatkan pengujian hipotesis dimana hipotesis tersebut dideduksi dari hipotesis lain yang tingkat abstraksinya atau perumusan konseptualnya lebih tinggi.

Paradigma positivis melihat ilmu sosial sebagai metode yang terorganisir untuk mengombinasikan logika deduktif dengan observasi empiris dari perilaku manusia yang bertujuan untuk mengetahui dan mengonfirmasi hukum kausal yang bisa memprediksikan pola umum aktivitas manusia. Paradigma positivis merupakan pandangan yang di dalamnya terdapat realitas objektif sebagai realitas eksternal di luar peneliti dimana peneliti harus menjaga jarak dengan objek penelitian, termasuk dalam hal nilai, etika, dan pilihan moral.

Penilaian subjektif dan bias pribadi harus bisa dipisahkan dari temuan penelitian. Penelitian ini menggunakan kerangka deduktif, dimulai dari pembentukan kerangka teori lalu membuat hipotesis sebagai jawaban tentatif bagi masalah penelitian yang akan diuji lebih lanjut melalui perangkat metodologi tertentu. Melalui penelitian empiris, hipotesis-hipotesis itu diuji kebenarannya. Bila teruji kebenarannya, maka hipotesis tersebut diakui sebagai fakta. Dengan adanya fakta-fakta baru, teori yang dipakai dalam penelitian dapat disempurnakan.

\section{HASIL DAN PEMBAHASAN}

Dari hasil pembahasan dan uraian tentang Pola Komunikasi Masyarakat Dieng Dalam Menyosialisasikan Ritual Ruwatan Di Dieng-Wonosobo, maka kesimpulannya. Pola komunikasi orang tua anak rambut gembel terhadap anak rambut gembel menerapkan komunikasi dua arah yaitu adanya timbal balik atau feedback dari orang tua ke anak rambut gembel. Sedangkan pola komunikasi pemerintah daerah terhadap masyarakat luar dalam menyosialisasikan ritual ruwatan potong rambut gembel menggunakan pola komunikasi Y dimana PERDA adalah pimpinan dari pola komunikasi in, pemangku adat dan masyarakat adalah anggotannya namun salah satu anggotanya bisa menjadi pimpinan dari pola komunikasi $\mathrm{Y}$.

Dalam menyosialisasikan ritual ruwatan kepada anak rambut gembel orang tua melakukan berbagai pendekatan sosialisasi. Salah satunya dengan menitik beratkan pada enkulturasi dimana anak rambut gembel diberikan pemahaman pada cerita dari mitos setempat, memberikan pemahaman pentingnya ruwatan bagi anak rambut gembel. Tanpa mengurangi nilai dari arti ritual ruwatan itu sendiri. 
Dalam mempertahankan identitas kebudayaan dari Dieng, PERDA melakukan berbagai sosialisasi kepada masyarakat luar dan masyarakat dieng sendiri, melalui membuat ritual ruwatan rambut gembel secara rutin. Pemerintah setempat memotivasi masyarakat Dieng berperan aktif mementaskan kesenian daerah untuk mempertahankan kebudayaan daerah dan mendukung dalam ritual ruwatan potong rambut gembel dengan cara menyosialisasikan kemasyarakat luar dengan cara membuat dieng culture festival, membuat web resmi Dieng dan lain-lain.

Makna ritual ruwatan bagi masyarakat dieng adalah memohon keselamatkan dan kesejahteraan dapat dilihat dari simbol verbal dan non verbal pada prosesi atau tatacara ritual ruwatan potong rambut gembel. Latar belakang timbulnya rambut gembel disebabkan oleh adanya sistem endogami dan faktor genetik, factor genetik ini tidak turun-menurun secara langsung. Factor lainnya masyarakat Dieng memiliki keyakian bahwa anak rambut gembel merupakan takdir Yang Maha Esa.

\section{KESIMPULAN}

Bagi orang tua anak rambut gembel, harus dapat membedakan agama (keyakinan), mitos dan adat. Pemahaman tersebut dapat diperdalam dengan membandingkan dengan berbagai sumber dan dalam menyosialisasikan ritual ruwatan potong rambut gembel ini dapat lebih rasionalitas. Bagi Pemerintah daerah setempat dalam menyosialisasikan ritual ruwatan potong rambut gembel guna membentuk identitas Dieng, harus tetap menjaga kelestarian ritual ruwatan itu sendiri dan lebih mengembangkan kemajuan pariwisata budaya dan promosi yang lebih menarik. Dalam ritual ruwatan potong rambut gembel, hendaknya masyarakat dataran tinggi Dieng tidak hanya sekedar mempertahankan suatu tradisi tetapi memiliki pesan moral dan sosial agar dapat dipertanggung jawabkan keberadannya di lingkungan tempat tinggal daerah setempat.

\section{DAFTAR PUSTAKA}

Dadan, A., Kresnowati, W. (2008). Komunikasi Antar Budaya konsep dan aplikasinya. Jakarta: Jala Permata

Daryanto. (2010). Ilmu Komunikasi. Bandung: PT.Sarana Tutorial Nurani Sejahtera.

Deddy, M. Rakhmat, J. (2005). Komunikasi Antar budaya. Bandung: PT.Remaja Rosdakarya.

DeVito, J.A. (2009). Komunikasi Antarmanusia. Jakarta: Profesional Books.

Fajar, M. (2009). Ilmu Komunikasi: Teori dan Praktik. Yogyakarta: Graha Ilmu.

Giri, W. (2010). Sajen dan Ritual Orang Jawa. Yogyajarta: Narasi.

Koentjaraningrat. (1980). Sejarah Teori Antropologi. Jakarta: UI Press

Kriyantono, R. (2006). Tehnik praktisi set komunikasi. Jakarta: Kencana.

Liliweri, A. (2007). Makna Budaya dalam Komunikasi Antarbudaya, Yogyakarta: LkiS

Mas'ud, T. (1989). Upacara Ruwatan Gagrak Surakarta Hadiningrat. Jawa Tengah: Taman Mini Indonesia Indah.

Moleong, L.J. (2005). Metodologi penelitian Kuantitatif. Bandung: PT. Rosdakarya.

Morissan. (2009). Teori Komunikasi Organisasi, Jakarta: Ghalia Indonesia.

Nazir, M. (1988). Metodologi Penelitian. Jakarta: Graha Indonesia.

Rakhmat, J. (2005). Metode Penelitian Komunisasi. Jakarta: Remaja Rosdakarya.

Santoso, T. \& Dyson, L. (1997). Ilmu Budaya Dasar. Surabaya: Citra Media. 